\title{
Cultivation of GMO in Germany: support of monitoring and coexistence issues by WebGIS technology
}

\author{
Lukas Kleppin ${ }^{*}$, Gunther Schmidt ${ }^{\dagger}$, Winfried Schröder ${ }^{\dagger}$
}

\begin{abstract}
Background: In Germany, apart from the Amflora potato licensed for cultivation since March 2010, Bt-maize MON810 is the only genetically modified organisms (GMO) licensed for commercial cultivation (about 3,000 ha in 2008). Concerns have been raised about potential adverse environmental impacts of the GMO and about potential implications on the coexistence between conventional and genetically modified production. These issues should be considered on a regional base. The objective of this article is to describe how GMO monitoring that is required after risk assessment and GMO release can be complemented by a Web-based geoinformation system (WebGIS). Secondly, it is also described how WebGIS techniques might support coexistence issues with regard to Bt-maize cultivation and conservation areas. Accordingly, on the one hand, the WebGIS should enable access to relevant geodata describing the receiving environment, including information on cultivation patterns and conservation areas containing protected species and habitats. On the other hand, metadata on already established environmental monitoring networks should be provided as well as measurement data of the intended GMO monitoring. Based on this information and based on the functionality provided by the WebGIS, the application helps in detecting possible environmental GMO impacts and in avoiding or identifying coexistence problems.
\end{abstract}

Results: The WebGIS applies Web mapping techniques to generate maps via internet requests and offers additional functionality for analysis, processing and publication of selected geodata. It is based on open source software solely. The developments rely on a combination of the University of Minnesota (UMN) MapServer with the Apache HTTP server, the open source database management systems MySQL and PostgreSQL and the graphical user interface provided by Mapbender. Important information on the number and the location of Btmaize fields were derived from the GMO location register of BVL. The "WebGIS GMO Monitoring" provides different tools allowing for the application of basic GIS techniques as, for instance, automatic or interactive zooming, distance measurements or querying attribute information from selected GIS layers. More sophisticated GIS tools were implemented additionally, e.g. a buffer function which enables generating buffers around selected geoobjects like Bt-maize fields. Finally, a function for intersection of different maps was developed. The WebGIS comprises information on the location of all Bt-maize fields in Germany according to the official GMO location register of the Federal Office of Consumer Protection and Food Safety between 2005 and 2008. It facilitates, amongst others, access to geodata of GMO fields and their surroundings and can relate them with additional environmental data on climate, soil, and agricultural patterns. Furthermore, spatial data on the location of florafauna-habitats and environmental monitoring sites in the federal state of Brandenburg were integrated. The WebGIS GMO monitoring was implemented according to the concept for an "Information System for Monitoring GMO" (ISMO) which was designed on behalf of the German Federal Agency for Nature Conservation. ISMO includes hypotheses-based ecological effects of GMO cultivation and suggests checkpoints for GMO monitoring to test whether impacts may be observed in the receiving environment.

\footnotetext{
* Correspondence: Ikleppin@iuw.uni-vechta.de

+ Contributed equally

University of Vechta, P.O. Box 1553, 49364 Vechta, Germany
}

\section{SpringerOpen ${ }^{\circ}$}

(c) 2011 Kleppin et al; licensee Springer. This is an Open Access article distributed under the terms of the Creative Commons Attribution License (http://creativecommons.org/licenses/by/2.0), which permits unrestricted use, distribution, and reproduction in any medium, provided the original work is properly cited. 
In contrast to the public GMO register, the WebGIS GMO monitoring enables mapping of GMO fields and provides relevant geodata describing environmental and agricultural conditions in their neighbourhood of the cultivation sites as well as information derived from monitoring sites. On this basis, spatial analyses should be enabled and supported, respectively. Further, the WebGIS GMO monitoring supplements PortalU which, in Germany, is the technical realisation of the Infrastructure for Spatial Information in Europe directive (Directive 2007/2/EC) released by the EU in 2007.

Conclusions: The article should have shown how to support and complement GMO monitoring with the help of the WebGIS application. It facilitates co-operation and data access across spatial scales for different users since it is based on internet technologies. The WebGIS improves storage, analysis, management and presentation of spatial data. Apart from the improved flow of information, it supports future long-term GMO monitoring and modelling of the dispersal of transgenic pollen, for instance. Additional information (e.g. data on wind conditions or soil observation sites) provided by the WebGIS will be helpful to determine representative monitoring sites for detecting potential GMO impacts by means of monitoring or modelling. Thus, the WebGIS can also serve as part of an early warning system. In the near future, the integration of locations of all Bt-maize fields in Germany into the WebGIS as a continuous task should be automatised. Additionally, a methodology should be developed to detect maize fields by means of remote sensing data to manage coexistence problems on the basis of actual field patterns.

\section{Background}

Genetic engineering was introduced to improve plant breeding. It enables to establish new varieties of plant species with specific input and output traits [1]. The cultivation of GMO aims at increasing yield, but also to improve product quality $[2,3]$. Input traits include resistances against different herbicides or insect pests and viruses. Output traits aim to improve the quality of agricultural products, e.g. increasing fibre or lowering the fat content. Worldwide, the cultivation of GMO increased from 1.7 Mio ha in 1996 up to 134 Mio ha in 2009 [4]. According to the agricultural statistical survey 2009 , for example in the USA, $90 \%$ of the cropland is used to cultivate GMO varieties of soy or cotton. In the USA, the percentage of genetically modified (GM) maize is already $85 \%$. In Germany, GMO (99\% Bt-maize MON810) were cultivated from 2005 until 2008 with a total number of 239 fields and a total acreage of 3,171 ha in 2008.

In contrast to the contained use of GM products in medicine, the introduction of GMO in agricultural ecosystems may cause unwanted, uncontrollable and irreversible impacts.

According to EU Directive 2001/18/EC, plant breeders willing to introduce GMO on the market have to accomplish a notification process including an environmental risk assessment (ERA) and a monitoring plan to the competent national and European authorities [5]. This regulatory framework is intended to implement the precautionary principle and to enable handling potential adverse environmental effects still remaining after the ERA [6]. The aim of the EU Directive 2001/18/EC is to safeguard human health and the environment and to restrict the use of GMO so that no unacceptable risks or hazards can emerge [7]. The risk assessment is based on empirical studies with small spatial extent, encompassing laboratories tests, greenhouse experiments, small-scale field release or commercial-scale field release [8-10]. Though, there remains a wide range of uncertainty with small plot and laboratory studies. According to scientific hypotheses, adverse effects are examined in the ERA. However, ERA concentrates at the small-scale level, thus, large-scale effects are difficult to assess. Thus, monitoring of GMO at the landscape scale is required after the GMO have been released to detect adverse environmental effects at regional or larger scale [11]. Accordingly, the EU Directive 2001/18/EC [5] on the deliberate release of GMO into the environment stipulates assessment of direct and indirect effects of GMO on humans and the environment by case-specific monitoring and general surveillance. The latter has to be performed to detect potential unanticipated adverse effects whereas case-specific monitoring is set up to reduce substantial uncertainties in relevant risk scenarios identified in the ERA [5]. In Germany, the Federal Nature Conservation Agency suggests how to implement a monitoring of GMO. Three core issues have to be covered: (1) documentation of exposure, (2) monitoring impacts of the specific GMO and (3) large-scale and long term-effect relationships [12]. The results of GMO monitoring contribute to decisions regarding, e.g. further approval or refusal of the GMO or additional precautions during cultivation. In this context, GMO monitoring provides the basis for an early warning system to react at an early stage in case of reported adverse effects and decide upon counter measures. Relevant topics have to be considered for both, case-specific monitoring and general surveillance, which are, for 
example, (a) combinatory effects of several genetic modifications accumulating in individual plants of a crop species such as multiple resistances in oilseed rape $[13,14]$, (b) effects of different Bt-toxins on susceptible butterfly populations [15-17] or (c) long-term effects due to changes in farming practices [18]. The necessity of monitoring adverse GMO effects can be pointed out by means of a few indications, for example, enhanced mortality of non-target organisms [6], hybridisation with related species [19] or neighbouring non-GM crops [20] and adverse agricultural practice changes [21]. According to EU Directive 2001/18/EC [5], a set of appropriate monitoring parameters has to be defined which are described in the guidelines for GMO monitoring as, for instance, published by the Association of German Engineers [22]. These obligate test items have to be considered when integrating and compiling data from already existing environmental monitoring networks [23-25].

In this context, a Web-based geographical information system (WebGIS) is appropriate to build up a data infrastructure for GMO monitoring and data exchange [26]. The objective of the article at hand is to describe how to complement and support GMO monitoring by the implementation of a WebGIS as suggested by Aden et al. [25]. The WebGIS enables access to relevant geodata like basic environmental information, existing monitoring networks related to GMO issues, details on GMO fields and information on protected areas as well as tools for collecting, processing and mapping monitoring results. Implemented GIS tools that do not require any additional software but an Internet browser at the client's computer should help in assessment of possible GMO impacts in a spatially discriminated context. On that score, the WebGIS can facilitate the approval process. Secondly, it could be used to manage coexistence of GMO, conventional and organic farming as well as with nature conservation issues by detecting or avoiding possible conflicts already during planning stage [27]. Moreover, the Web-based application will provide spatial information on the locations of the Bt-maize fields which can be used for modelling cross-pollination of GM maize pollen at field scale, for instance, to check, e. g. whether distance regulations between Bt-maize and conventional maize fields are sufficient or not [28].

\section{Materials and methods}

Open source software and standards

The use of proprietary software is being determined by licences and copyrights; annual license fees may be imposed. Sharing or modification of this software is strictly forbidden. Due to the business concept of proprietary software, the source code is not accessible [29]. Open source software offers an approved alternative to proprietary software. However, there is no guarantee that the open source software is working properly. Compared to proprietary software, open source products are prescribed to be free of charge and the source code is disclosed and free for modifications. Open source software is not confined to private use, but is adopted from business companies, public facilities as well as from authorities. It is used in all fields of information technology, for instance, as operating system (Linux, HostGIS), complementary software (hypertext transfer protocol (HTTP) Server, CMS, MapServer, WebGIS-Clientsuites), and independent GIS software (GRASS-GIS, JUMP) [29]. Open source is specified by several criteria of the Open Source Initiative [30,31].

Open source software used to build up the Web application described in the article at hand follows the standards of the Open Geospatial Consortium (OGC). This is an international organisation composed of business companies, universities and authorities. The OGC releases standards for interfaces to process various types of geodata via Internet. Standards and specifications are supposed to ensure interoperability between map services located anywhere in the world and to provide access to complex spatial information. The EU directive Infrastructure for Spatial Information in Europe (INSPIRE) [32] and the German PortalU [33] already comply with these standards.

\section{System architecture}

Based on open source software and in accordance with the INSPIRE standards, we developed the "WebGIS GMO Monitoring". To this end, a server programme was used which provides the functionality of a "spatial" communication. Our recent developments rely on a combination of the UMN MapServer with the Apache HTTP server. The main function of the HTTP server relies on the communication with Web clients. Map servers are components that perform queries and analyses of both raster and vector data and generate and display maps in a uniform projection defined by the user. We then installed the database management system PostgreSQL enhanced with the spatial extension PostGIS. Open source database systems like MySQL and PostgreSQL are capable to save and process spatial information and related attributes in additional libraries (MyGIS, PostGIS). The spatial extension PostGIS acts as GIS back end which allows performing basic GIS operations on geodata without expensive programming. The integration of the GIS back end GRASS is an essential part of the current work. The WebGIS interactively enables advanced GIS techniques and geodata analyses. For this purpose, the user only needs a Web browser (Mozilla, MS Internet Explorer) but no additional GIS software. Finally, we installed the WebGIS-Client Suite Mapbender by CCGIS http://www.mapbender.org which provides the user interface. The open source product 
offers various tools for navigation within maps, retrieval of metadata and queries of map contents [34]. Moreover, it is possible to integrate remote Web Map Services to build up a more extensive data infrastructure for environmental monitoring issues.

\section{GMO location register}

The Federal Office of Consumer Protection and Food Safety (Bundesamt für Verbraucherschutz und Lebensmittelsicherheit, BVL) is the competent authority charged with the enforcement of the Genetic Engineering Act (Gentechnikgesetz, GenTG) and the legislation of the European Union. The BVL, correspondingly, assesses notifications for the experimental use of GMO and also gives advice to the Federal Government as well as to the Federal States and their bodies on issues of biological safety in genetic engineering. The BVL maintains the GMO location register [35]http://www.bvl.bund.de as well as the GMO notification register, serving as an information platform on GMO release for the public. The BVL is committed to record information on GMO cultivation in the register by the EU Directive 2004/204/EC [36]. This is to improve monitoring of possible negative long-term effects with regard to environment, human and animal health. Additionally, the GMO location register should assure transparency and should help adjacent farmers to cultivate GM crops and non-GM crops without cross-pollination (coexistence). The GMO location register contains the identification numbers (ID) of GMO fields related to the Amtliches Liegenschaftskataster (ALK). However, the GMO location register is not linked with the ALK and has only very limited options for cartographic visualisation, i.e. it is only possible to map the cultivation of Bt-maize at the level of municipalities in terms of density maps [37]. A visualisation of $\mathrm{Bt}$-maize fields is not possible by the location register and, thus, it is not possible to identify single GMO fields by spatial queries or mapping.

The application WebGIS GMO monitoring improves these techniques and provides corresponding information to implement required monitoring issues (GenTG, chapter 3,15$)$. As a first step of development and implementation, the WebGIS was designed only for the Federal State of Brandenburg. The localisation of the GMO fields in Brandenburg was enabled by identification of the land parcels where the Bt-maize was cultivated using the ID field of the ALK listed in the GMO location register. Difficulties arise when no public cadastre (ALK) is available for free to spatially reference according GM maize fields (see "Conclusions").

\section{Results}

\section{Database}

Geodata having been integrated in the WebGIS application are essential for GMO monitoring issues because in various ways they can help detect possible impacts or coexistence problems due to GMO cultivation. The application provides maps on land use patterns of CORINE Land Cover [38], on ecological landscape units [39] and on ecoregions [40] as well as satellite images of Northern Germany, phenological data on maize plants and averaged measurements on precipitation (19611990), temperature (1961-1990), sunshine duration (1961-1990), wind direction and evaporation rate compiled from the German Weather Service (DWD). Furthermore, maps on cultivation intensity of several crops at district level derived from agricultural statistics (Statistik lokal 1999, 2003, 2007) [41] and data on Btmaize cultivation derived from the public GMO register were integrated. In addition to the developmental stage of the WebGIS as published by Kleppin et al. (2008) [42], supplementary data were integrated in the WebGIS GMO monitoring: information on the location of faunaflora-habitats (FFH) in the federal state of Brandenburg including a list on protected species [43], data on monitoring programmes in Brandenburg with regard to longterm soil observation sites, groundwater and surface water observation sites as well as monitoring sites within biosphere reserves [44] including a list of analysed parameters. Finally, the database was updated with information on the occurrence of the European corn borer (Ostrinia nubilalis) from 2005 until 2007 being the target organism for the introduction of Bt-maize. All geodata and according attributes are described by metadata which can be modified or completed if necessary. The WebGIS administrator is authorised to decide whether actual geodata may be downloaded by user request. By this, users get distinct access rights for predetermined information.

\section{The WebGIS GMO monitoring}

The WebGIS GMO monitoring provides a graphical user interface based on the Mapbender software (Figure 1). A tool bar allows applying basic GIS techniques (see Figure 1, item 3), for instance, automatic or interactive zooming, distance measurements or querying attribute information from selected GIS layers. A detailed map including a scale bar and navigation buttons show the selected layers (see Figure 1, item 5). A small-scale reference map depicts the geographical location of the selected area displayed in the detailed map (see Figure 1, item 2 ). The layer tool enables management of geo-objects (see Figure 1, item 1). By activating the checkboxes, each layer is drawn in the map window (left checkbox in item 1) or attribute queries can be enabled (right checkbox in item 1). Corresponding to the chosen layers, legends are generated automatically (see Figure 1, item 4). The selected layers 'Cultivation 2008' (A) and 'GMO sites' (B) displayed in Figure 1 show (A) the 


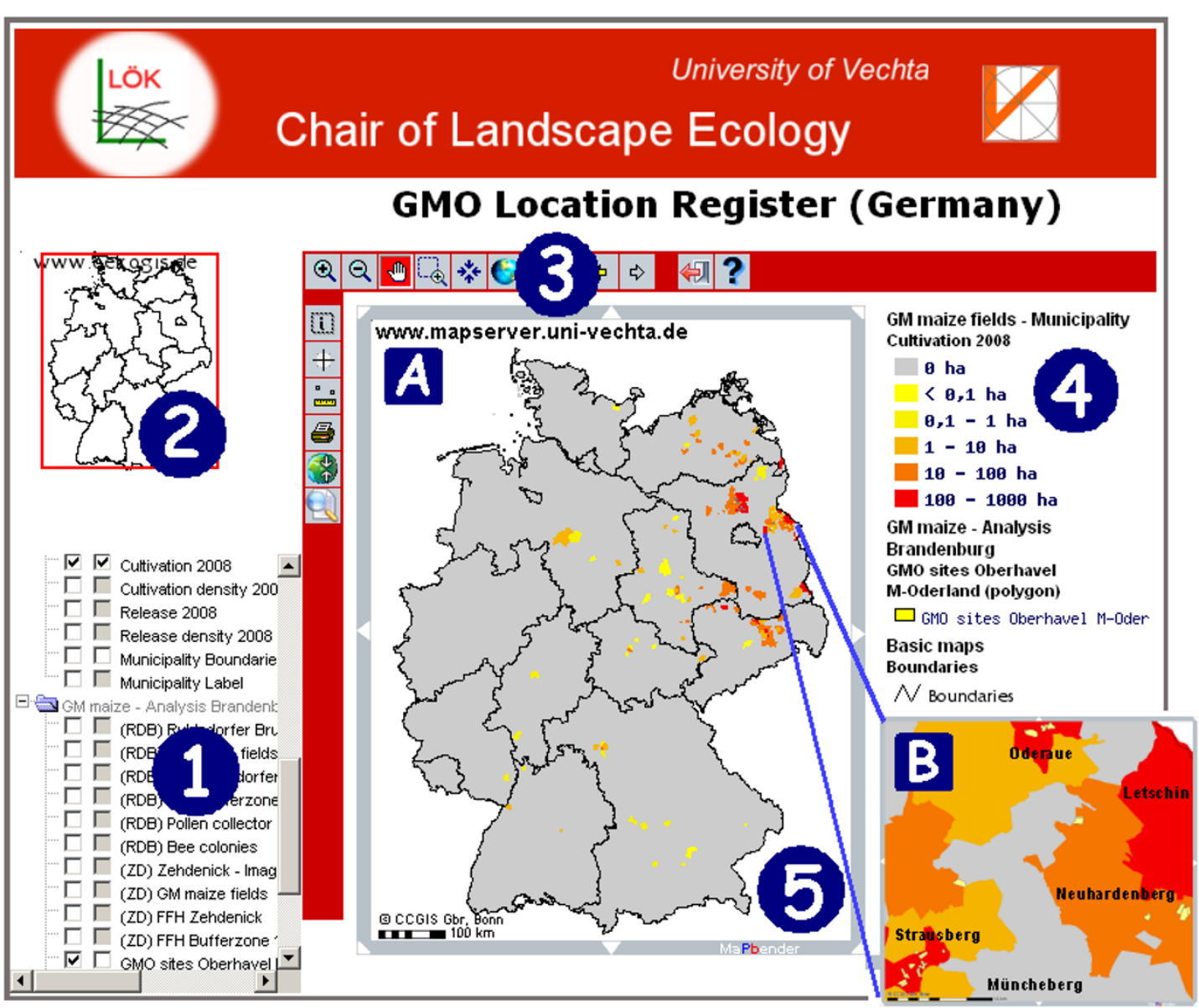

Figure 1 WebGIS GMO monitoring displaying percentage of Bt-maize fields. (a) In relation to total maize cropland and (b) a detailed map on the allocation of Bt-maize fields in Brandenburg (yellow).

cultivation area of Bt-maize fields for each municipality in 2008, and (B) in detail single Bt-maize fields in Brandenburg which were registered by the BVL in 2008. The map on Bt-maize fields can be complemented by displaying additional geodata, like, for instance, maps on land use patterns or ecoregions as, e.g., published by Schröder and Schmidt (2001) [40]. Additionally, maps on the location of nature reserves can be overlaid with locations of Bt-maize fields. By clicking on the layer's name in the WebGIS application, available metadata describing source, date of origin and other relevant information on the data set are listed in tables.

Beyond the developmental stage of the WebGIS as reported by Kleppin et al. (2008) [42], the WebGIS GMO monitoring was improved by the implementation of sophisticated GIS tools. A buffer function allows generating buffers around selected geo-objects like, for instance, Bt-maize fields (Figure 2B). Another function ("contain") allows listing of all geo-objects being located within a certain buffer zone (Figure 2D). An "intersect" function (Figure 2C) can be used for spatially relating different layers. Two special intersect cases were realised, such as "clip" and "union". "Clip" can be used to cut out features of one layer with one or more features of another layer. The function "union" calculates the geometric intersection of all features of two layers. The output features will then have the attributes of both layers. Further, it is possible to calculate distances between geo-objects (Figure 2E) and, finally, a query tool was implemented to identify distinct GMO fields. It is also possible to generate buffer zones around single or several (Bt-)maize fields in a given municipality by specifying a buffer name and the desired extent of the buffer zone. The username is necessary to generate unique names for both the new layer (see Figure 2B). While the buffer zone is calculated, the map file, which defines the layout of the new geo-object, is generated automatically too, and integrated into the user interface of the Mapbender software ("The WebGIS GMO monitoring"). Additionally, the new buffer zone as well as the respective SRID (Spatial Reference Identifier) and the type of the geometry are registered dynamically in 


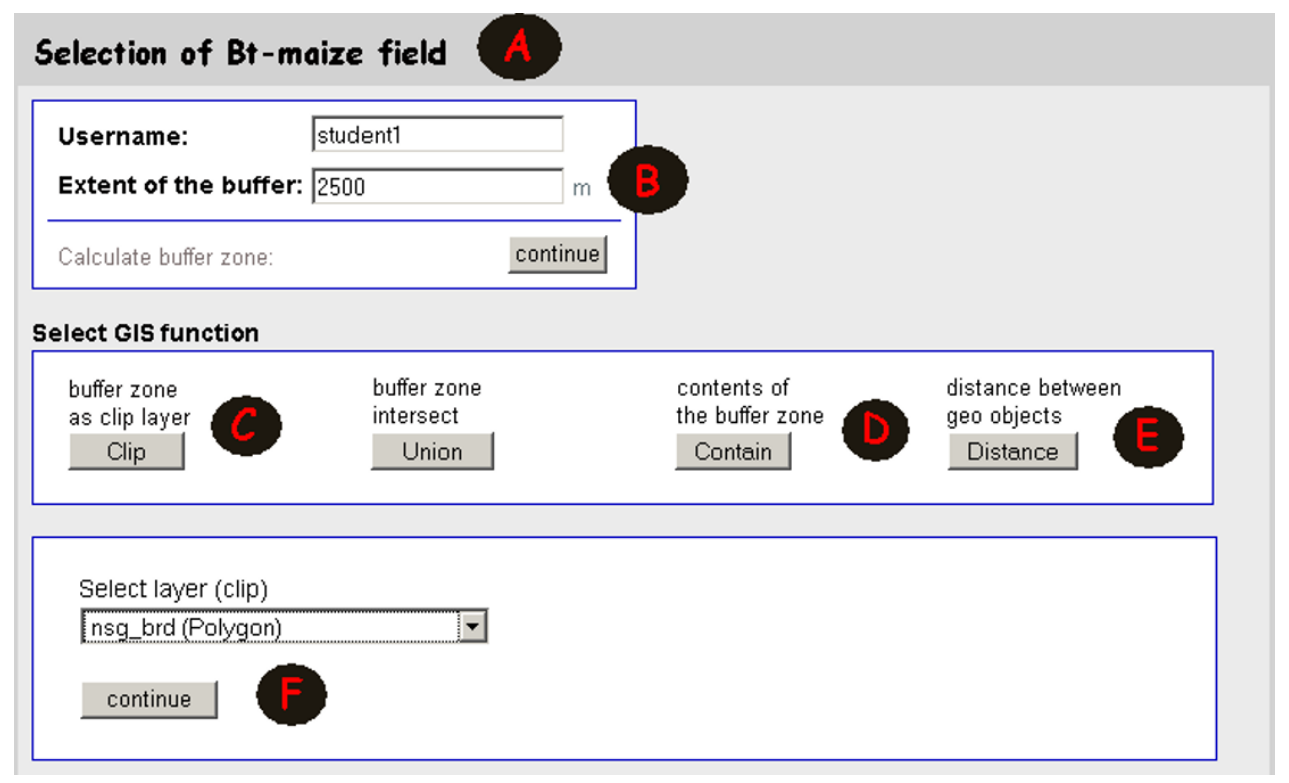

Figure 2 GIS operations for analysing geo-objects (Bt-maize fields).

the geodatabase. For displaying the new layer it is necessary to update the webpage (Figure 3 ). The new bufferlayer can be intersected with other geodata stored in the geodatabase (Figure 2F). Further, an according template file provides specific information which describes the selected area or location by coordinates, name, size, etc. After log out, all files and geodata generated before are deleted in order to save storage capacity. Additional extensions for printing maps or downloading the individually generated files are under construction.

As an example, in Figure 2A, a certain Bt-maize field is selected to generate a buffer zone of 2,500 $\mathrm{m}$ around this field. As a result, the extent of the buffer appears in the map as a blue polygon (see Figure 3 ). In the next step, the user extracts geo-objects from the FFH layer by clipping with the buffer layer generated before (see Figure $2 \mathrm{C}, \mathrm{F}$ ). In the result, one single FFH area is highlighted (red outline) being located within the buffer zone (see Figure 3). Additionally, the extracted FFH area is linked to a query template to provide specific information, for instance, on protected species housed in this FFH area. This spatial investigation whether the Btmaize fields are within or near a conservation area is relevant since protected non-target organisms might be affected by toxins produced by Bt-maize or a change in biodiversity might be induced. Furthermore, it is possible to calculate the distance between the selected Btmaize field and the respective conservation area (see Figure 2E) and to identify other relevant geodata located within the buffer zone (see Figure 2D).

In case local authorities plan to conduct a case-specific GMO monitoring, buffer zones around all Bt-maize fields of the respective municipality might be generated at first. In a second step, it could be checked automatically whether monitoring sites of related environmental monitoring networks ("Database") are located within the buffer zones. Regarding the respective GMO, it could be checked in detail what measurements are taken at these sites in order to support analysis of possible adverse effects. For instance, data on wind conditions can be evaluated in order to determine favourable sites for technical pollen samplers [45]. Projected GM pollen loads help in assessing risks for non-target organisms (NTO) occurring in the vicinity of GMO fields. In this context, Rosi-Marshall et al. (2007) [46] found out in laboratory feeding trials that consumption of Bt-corn byproducts reduced growth and increased mortality of NTO stream insects.

Another benefit of the WebGIS GMO monitoring refers to coexistence issues. Generally, coexistence refers to the choice of consumers and farmers between conventional, organic and GM crop production. Thus, the aim is to accomplish a spatial segregation between GM and non-GM production at the landscape level which helps to avoid cross-pollination and seed contamination. Similarly, conflicts between GMO cultivation and protection goals concerning conservation reserves have to be avoided. By use of the WebGIS, farmers cultivating conventional maize are enabled to check distances to adjacent Bt-maize fields with regard to distance regulations defined in the amendment of the GenTG (150 m to conventional fields, $300 \mathrm{~m}$ to organic fields). This also applies to protected areas with respect to nature conservation issues $(800 \mathrm{~m}$ in the federal state Brandenburg). 


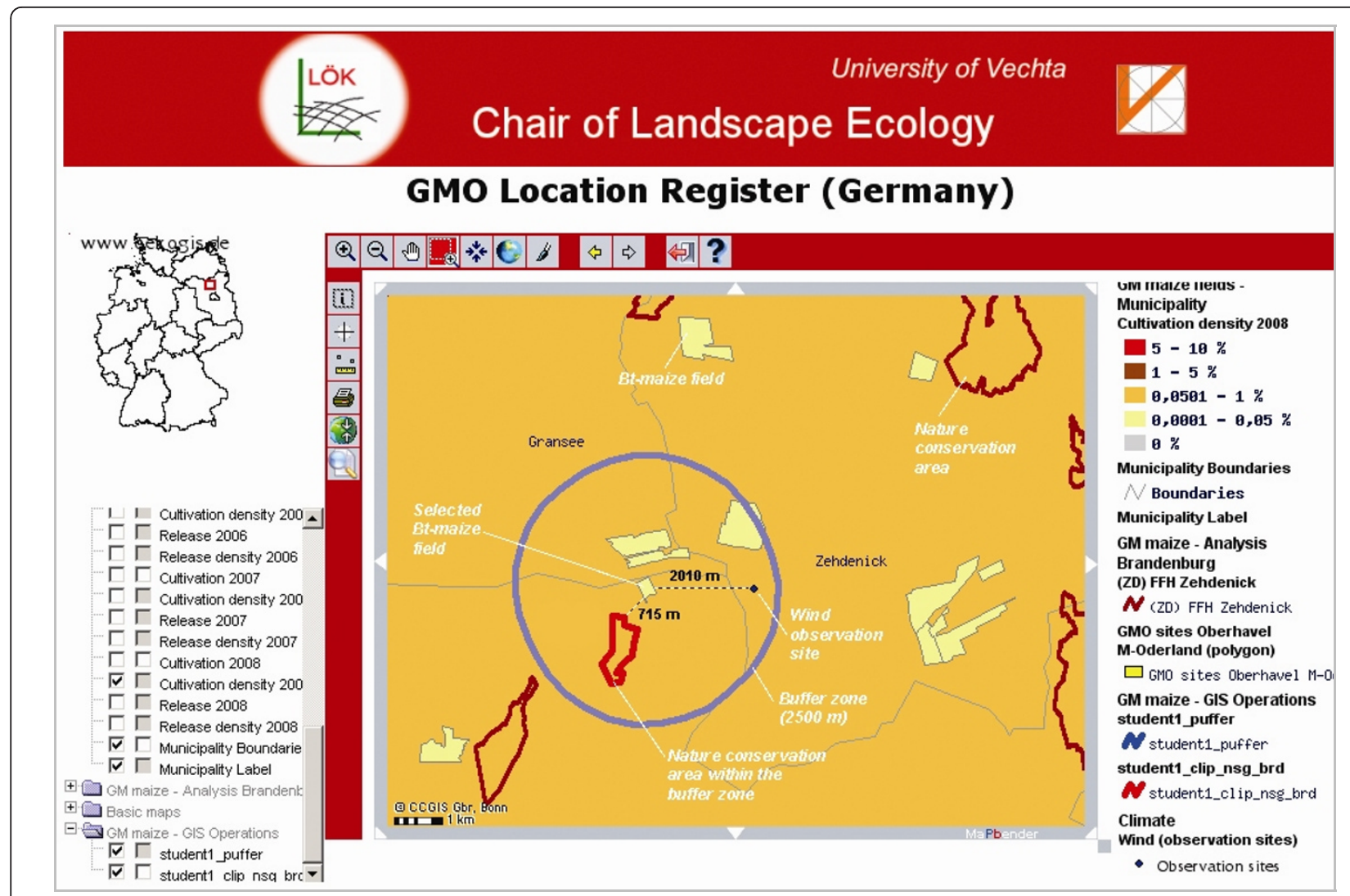

Figure 3 WebGIS GMO monitoring showing the visualisation of different geodata in the layer folder (GM maize-GIS Operations).

The localisation of regions where Bt-maize can be cultivated without impairing conventional maize fields or nature reserves is a challenging task. In a GIS-based approach, conventional maize fields and conservation areas have to be buffered in accordance to existing distance regulations. The cropland outside the buffered area would be eligible for Btmaize cultivation [47]. Furthermore, all FFH conservation areas in Brandenburg are documented by subjects of protection (e.g. endangered species). In order to identify all the FFH conservation areas which might probably be affected by pollen dispersal, it is necessary to generate a buffer of $800 \mathrm{~m}$, as defined by the federal authorities, around these areas. In the next step, the according buffer zones must be intersected with the geometries of the $\mathrm{Bt}$-maize fields to identify whether some of these Btmaize fields are located within the respective buffer zone. Afterwards, it can be tested whether any endangered species (NTOs) occur in the respective protection areas which might be exposed to Bt-maize pollen. Laboratory tests have shown that Bt toxins may influence NTOs in growth and physical condition $[48,46]$.

\section{Discussion}

GMO monitoring should take place in areas exposed to GMO, preferably cultivated fields and their environment, but should include also regions with no or unknown GMO exposure. On a case-by-case basis depending on the GMO characteristics, the selected indicators, checkpoints and related analytical methods should consider relevant different spatial and temporal scales $[49,22]$. Hence, the monitoring of ecological effects of GMO must be standardised with regard to parameters, methods, survey intervals and sites so that data are comparable in terms of measurement methods and, thus, can be analysed statistically and interpreted meaningfully [22]. This comprises standards concerning molecularbiological detection methods, vegetation mapping and faunistic surveys to evaluate changes in population density and behaviour of endangered species, for example. This standardisation is to ensure a Germany-wide comparability of sampling data and to provide legal certainty for the user [50]. Accordingly, the WebGIS GMO monitoring should support realisation of particular parts of the guideline VDI 4330 [22]: "Monitoring the ecological effects of genetically modified organisms - Basic principles and strategies" (VDI 4330, part 1), "Pollen monitoring: Pollen sampling using pollen mass filters (PMF) and Sigma-2 samplers" (VDI 4330, part 3), "Pollen monitoring: Biological sampling by honey bees" (VDI 4330, part 4). In this context, Reuter et al. $(2006,2010)[23,24]$ 
developed a concept of an information system for GMO monitoring (ISMO). The database concept encompasses three components: The "Knowledge Database" comprises information related to different levels of biological organisation being affected by GMO cultivation. Therein, scientific hypotheses regarding ecological effects of GMO as well as checkpoints for monitoring possible impacts were described in detail. The "Monitoring Database" should provide GMO monitoring data and interfaces to existing environmental information systems being of relevance for GMO monitoring issues. The WebGIS GMO monitoring is designated to be part of the monitoring database enabling data retrieval, mapping and analysis of relevant monitoring data and geodata. The "Administrative Database" structures all data necessary for the approval process. ISMO enables support by competent authorities in the notification process and post market monitoring of environmental effects [24]. Checkpoints defined by ISMO were used to compile and integrate appropriate environmental monitoring programmes in the WebGIS GMO monitoring.

Compared with the public register of the BVL, advantages of the WebGIS GMO monitoring are obviously the possibility to map registered GMO fields as well as to perform spatial analyses by additional relevant geodata useful for GMO monitoring issues and environmental risk assessment. The use of licence-free open source software for assembling the application is another advantage compared with the public register of the BVL which is based on proprietary software. The WebGIS GMO monitoring is not intended to compete with the public register of the BVL, but it serves as a supplement for more transparency regarding the localisation and management of single GMO fields and agricultural patterns.

The Federal Nature Conservation Agency provides another WebGIS application [51] which allows displaying Natura 2000 reserves as well as predefined buffer zones of 1,000 $\mathrm{m}$ around them. An interactive query offers additional information on the respective nature reserve, like name and site code. Specific information on protected species in general or species that might be affected by GMO cultivation individually is not provided.

Another application called "Risk Register Genetic Engineering Agriculture” [52] displays, for instance, all Bt-maize fields cultivated in 2009 and 2010 in Germany. The respective field geometries were derived by using Google Maps. Additional thematic maps were integrated on the basis of the official GMO location register of the BVL displaying static density maps of GMO cultivation on different administrative levels and for different periods and crops. However, this application just visualises GMO fields, whereas the WebGIS GMO monitoring additionally enables performing GIS procedures. Furthermore, interactive dynamic generation of buffers and intersection with additional geodata enhance the WebGIS functionalities in terms of spatial analysis. For instance, it is possible to intersect data on Bt-maize fields with additional geodata like related monitoring sites or distribution maps of the corn borer as being the target object for Bt-maize cultivation. Furthermore, the WebGIS GMO monitoring facilitates linkage to PortalU [53] as being the German realisation of the European INSPIRE directive [33] which aims at "establishing an infrastructure for spatial information in Europe to support Community environmental policies, and policies or activities which may have an impact on the environment". Accordingly, data from the WebGIS GMO monitoring will enhance the database of PortalU and enable remote geodata access without implementation of a local GIS software at the client PC.

Compared to the work published by Kleppin et al. (2008) [42], the database was complemented by additional geodata, e.g., on environmental monitoring networks and the respective information on measurement parameters. Apart from that, the WebGIS GMO monitoring was optimised and improved by the implementation of additional sophisticated GIS techniques including buffer and intersect tools. However, longterm risks of GMO cultivation are difficult to assess, in particular, because possible impacts depend on spatially varying conditions [54]. Anticipating risks is often hampered by limitations in scientific knowledge or in availability of data, in particular, in cases where a complex process of change is continuing (e.g. climate change) or a new technological context is added to an established interaction network. An increasing amount of information can be accessed via the Internet. Particular in recent years, attention has focused on the presented WebGIS technology which enables compilation and access to data, e.g., affecting the dispersal of GMO, such as wind speed and direction. However, GIS is not only used for pre-event vulnerability assessment but can be used also for improving preparedness, mitigation, monitoring and response plan activities. Thus, the use of WebGIS provides instructive links with administrative, socioeconomic and other data, and enhances communication of the results to policy makers and the public. This communication dimension is fundamental - local people need to incorporate risk awareness into their culture [55].

\section{Conclusions}

According to Wilkinson et al. (2000) [56] and Züghart and Breckling (2003) [57] criteria for selecting monitoring sites and regions include 1) representativeness of sites cultivated with specific GMO, 2) representativeness 
of ecological regions containing the spectrum of relevant indicators, 3) availability of sites already monitored within other environmental programmes, and 4) areas with environmental conditions facilitating spread or survival of GMO. The WebGIS GMO monitoring supports this task by providing data on the distribution of GMO fields as well as on the distribution of monitoring sites of different environmental monitoring programs and, thus, helps in selecting appropriate monitoring sites. Furthermore, the article at hand demonstrates that the use of the WebGIS GMO monitoring is a useful and efficient tool to assess the individual and spatial risk potential before and during GMO release since it can be used to identify coexistence problems between Bt-maize and conventional maize cultivation on the one hand and between Bt-maize cultivation and conservation issues on the other hand.

Since in the future number and location of GMO fields might change considerably, the integration of geometries of Bt-maize fields into the WebGIS should be improved by an automation of the update procedure. Difficulties arise when no free Web services on ALK data are available to locate the respective GMO fields precisely. This is the case for about one third of all federal states in Germany. A possible solution is to compile the information directly from land registry offices. But this causes additional costs and is very time consuming. In this context, access to the 'Integrated Administration and Control System' (IASC, in German: InVeKoS = Integriertes Verwaltungs- und Kontrollsystem) would be a better and more efficient solution. Referring to this, in 1992 in the course of the reform of the 'Common Agriculture Policy' (GAP) the implementation of an 'IASC' was decided. It was introduced in Germany as per regulation no. 1782/2003 on December 3th 2004 (BGBl. 1 p. 3194) in order to define cultivation premiums. However, a nationwide information system on spatial and temporal cultivation patterns integrating agricultural data of all federal states has not been established, yet. In completion with information provided by the official GMO location register, such information platform could be used for detection of potential conflict regions with regard to conventional and Bt-maize cultivation. Since access to these data is not possible so far, future work aims at detection of maize fields by remote sensing data to integrate these data into the WebGIS application.

Furthermore, pollen dispersal plays an important part in the spread of GMO. Thus, currently the dispersion model AUSTAL2000 developed by the German Environmental Protection Agency [58] is being implemented in the WebGIS GMO monitoring. The Lagrange particle model considers time-dependent emissions from road and industrial sources. Modification of this software should enable simulation of Bt-maize pollen dispersal to quantify pollen load into conservation areas or conventional maize fields. Further, the dispersion model could help to establish a pollen monitoring network based on technical samplers or biological sampling by bees with respect to VDI 4330, parts 3 and 4 described by Hofmann et al. (2010) [45].

\section{Authors' contributions}

LK developed the WebGIS GMO monitoring and drafted the manuscript. GS composed the section Backgrounds and participated in the development of useful GIS operations. WS concentrated on the chapters Discussion and Conclusions. All authors read and approved the final manuscript.

\section{Competing interests}

The authors declare that they have no competing interests.

Received: 15 December 2010 Accepted: 2 February 2011 Published: 2 February 2011

\section{References}

1. Pickardt T, de Kathen A: Gentechnisch veränderte Pflanzen mit neuen oder verbesserten Qualitäts- und Nutzungseigenschaften: Futtermittel und rohstoffliefernde Nutzpflanzen, Pflanzen zur Bodensanierung und Zierpflanzen BioTechConsult. Berlin; 2004, 1-107.

2. Squire $G R$, Hawes $C$, Begg GH, Young MW: Cumulative impact of GM herbicide tolerant cropping on arable plants assessed through speciesbased and functional taxonomies. Environ Sci Pollut Res 2008, 16:85-94.

3. Wünn J: Landwirtschaft und Ernährung: Was bringen die neuen Entwicklungen für Bauern und Verbraucher? In Pflanzenbiotechnologie in der Schweiz. Ein Jahr nach der "Gentechfrei-Initiative". Bericht zur Fachtagung des Zürich-Basel Plant Science Center Edited by: Kohler S, Maranta A, Sautter Ch. Zürich 2007, 6-9.

4. James C: Global Status of Commercialized Biotech/GM Crops: 2009 - The first fourteen years, 1996 to 2009. ISAAA Executive Summary, Brief No. 41. Ithaca, NY [http://www.isaaa.org].

5. EC: EU Directive 2001/18/EC of the European Parliament and of the council 12 March 2001 on the deliberate release into the environment of genetically modified organisms and repealing Council Directive 90/ 220/EE. 2001, L106:1-38.

6. Sears MK, Hellmich RL, Stanley-Horn DE, Oberhauser KS, Pleasants JM, Mattila HR, Siegfried BD, Dively GP: Impact of Bt corn pollen on monarch butterfly populations: a risk assessment. PNAS 2001, 98:11937-11942.

7. EFSA-Q-2003-005: Guidance document of the scientific panel on genetically modified organisms for the risk assessment of genetically modified plants and derived food and feed (Question No EFSA-Q-2003005)., Adopted on 24 September 2004, updated on 7 December 2005, final edited version of 28 April 2006, May 2006.

8. Chapman MA, Burke JM: Letting the gene out of the bottle: The population genetics of genetically midified crops. New Phytologist 2006, 170:429-443.

9. Devaux C, Lavigne C, Austerlitz F, Klein EK: Modelling and estimating pollen movement in oilseed rape (Brassica napus) at the landscape scale using genetic markers. Mol Ecol 2007, 16:487-499.

10. Spök A, Hofer H, Lehner P, Valenta R, Stirn S, Gaugitsch H: Risk assessment of GMO products in the European Union. Toxicity assessment, allergenicity assessment and substantial equivalence in practice and proposals for improvement and standardisation. Wien 2005, [Berichte, BE253].

11. Craig W, Tepfer M, Degrasi G, Ripandelli : An overview of general features of risk assessments of genetically modified crops. Euphytica 2008, 164:853-880

12. Züghart W: Long-term and large-scale effects of genetically modified organisms require specific environmental monitoring designs. In Implications of GM-Crop Cultivation at Large Spatial Scales. Edited by: Breckling B, Reuter H, Verhoeven R. Frankfurt: Peter Lang; 2008:81-85, [Theorie in der Ökologie 14]. 
13. Beckie HJ, Warwick SI, Nair H, Seguin-Swartz G: Gene flow in commercial fields of herbicide-resistant canola (Brassica napus). Ecol Appl 2003, 13:1276-1294

14. Knispel AL, Mclachlan SM, Van Acker RC, Friesen LF: Gene flow and multiple herbicide resistance in escaped canola populations. Weed Sci 2008, 56:72-80

15. Dively GP, Rose R, Sears MK, Hellmich RL, Stanley-Horn DE, Calvin DD, Russo JM, Anderson PL: Effects on monarch butterfly larvae (Lepidoptera: Danaidae) after continuous exposure to Cry1ab-expressing corn during anthesis. Environ Entomol 2004, 33:116-1125.

16. Lang A, Vojtech $\mathrm{E}$ : The effects of pollen consumption of transgenic Bt maize on the common swallowtail, Papilio machaon L. (Lepidoptera, Papilionidae). Basic Appl Ecol 2006, 7:296-306.

17. Losey JE, Rayor LS, Carter ME: Transgenic pollen harm monarch larvae. Nature 1999, 399:214.

18. Graef F: Agro-environmental effects due to altered cultivation practices with genetically modified herbicide-tolerant oilseed rape and implications for monitoring. A review. Agronom Sustain Dev 2009, 29:31-42.

19. Lefol E, Fleury A, Darmency H: Gene dispersal from transgenic crops. II. Hybridization between oilseed rape and the wild hoary mustard. Sex Plant Reprod 1996, 9:189-196.

20. Rieger MA, Lamond M, Preston C, Powles SB, Roush RT: Pollen-mediated movement of herbicide resistance between commercial canola fields. Science 2001, 296:2386-2388.

21. Graef F, Stachow U, Werner A, Schütte G: Agricultural practice changes with cultivating genetically modified herbicide-tolerant oilseed rape. Agricult Syst 2007, 94:111-118.

22. VDI (Verein Deutscher Ingenieure): Beobachtung ökologischer Wirkungen gentechnisch veränderten Organismen - Gentechnisch veränderte Pflanzen Grundlagen und Strategie VDI 4330, Blatt 1. Düsseldorf; 2006.

23. Reuter $H$, Verhoeven $R$, Middelhoff $U$, Breckling B: Information system for the monitoring of genetically modified organisms (GMO) - ISMO. J Verbr Lebensm 2006, 1:89-91.

24. Reuter H, Middelhoff U, Graef F, Verhoeven R, Batz T, Weis M, Schmidt G, Schröder W, Breckling B: Information system for monitoring environmental impacts of genetically modified organisms. Environ Sci Pollut Res 2010 [http://dx.doi.org/10.1007/s11356-010-0334-y].

25. Züghart W, Benzler A, Berhorn F, Sukopp U, Graef F: Determining indicators, methods and sites for monitoring potential adverse effects of genetically modified plants to the environment: the legal and conceptional framework for implementation. Euphytica 2008, 164:845-852.

26. Aden C, Schmidt G, Schröder W: Ein webbasiertes Geografisches Informationssystem für das Monitoring gentechnisch veränderter Organismen. In GVO-Monitoring vor der Umsetzung. Bonn Edited by: Breckling B, Dolek M, Lang A, Reuter H, Verhoeven R 2007, 97-112, [Bundesamt für Naturschutz (Series Editor): Naturschutz und Biologische Vielfalt, 49].

27. Schmidt G, Schröder W: Auswahl repräsentativer Standorte zur Modellierung der Ausbreitung von gentechnisch veränderten Pflanzen in Nord-Deutschland. Umweltwiss Schadst Forsch 2008, 20:9-23.

28. Breckling B, Reuter $H$, Middelhoff $U$, Glemnitz M, Wurbs A, Schmidt G, Schröder W, Windhorst W: Risk indication of genetically modified organisms (GMO). Modelling environmental exposure and dispersal across different scales. Oilseed rape in Northern Germany as an integrated case study. Ecol Ind 2009.

29. Spath D, Günther J: Open Source Software - Strukturwandel oder Strohfeuer? Eine empirische Studie zu Trends und Entwicklungen zum Einsatz von Open Source Software in der öffentlichen Verwaltung und IT-Unternehmen in Deutschland [http://www.iao.fraunhofer.de/d/oss_studie.pdf]

30. GNU General Public License Versions. [http://www.opensource.org/ licenses/gpl-license.php].

31. Williams S: Free as in Freedom. Richard Stallman's Crusade for Free Software Cambridge: O'Reilly, Sebastopol; 2002.

32. INSPIRE Directive 2007/2/EC. [http://inspire.jrc.ec.europa.eu/]

33. Umweltportal Deutschland-PortalU. [http://portalu.de].

34. Adams T, Biakowski C, Christl A, Emde A, Thelen B, Trakas A: Praxishandbuch WebGIS mit Freier Software. Architektur, Beschreibung, Technik und Beispiele mit den Open Source Projekten: UMN MapServer AVeiN!, PostgreSQL/Post-GIS, Mapbender. CCGIS GbR/terrestris GbR/GeoConsortium. Bonn 2004.
35. GMO location register of the BVL. [http://apps2.bvl.bund.de/stareg_web/ showflaechen.do].

36. EC: EU Directive 2004/204/EC: Commission Decision of 23 February 2004 laying down detailed arrangements for the operation of the registers for recording information on genetic modifications in GMOs, provided for in Directive 2001/ 18/EC of the European Parliament and of the Council (Text with EEA relevance) (notified under document number C(2004) 540) 2004, L65:20-22.

37. Vaasen A, Gathmann A, Storch J, Bartsch D: Public GMO location register in Germany 2008 - a continuously improved information platform. Journal of Consumer Protection and Food Safety 2008, 29-31.

38. Keil M, Kiefl R, Strunz G: CORINE Land Cover 2000 - Germany. Final report. Project period: 1 May 2001 - 31 December 2004. German Remote Sensing Data Center Oberpfaffenhofen; 2005.

39. Meynen E, Schmithüsen J, Gellert J, Neef E, Müller-Miny H, Schultze JH: Handbuch der naturräumlichen Gliederung Deutschlands. Bad Godesberg, 2 Bde 1953, 1962.

40. Schröder W, Schmidt G: Defining ecoregions as framework for the assessment of ecological monitoring networks in Germany by means of GIS and classification and regression trees (CART). Gate to EHS 2001, 1-9.

41. Agricultural statistics - Statistik lokal 1999, 2003, 2007. [http://www. destatis.de/jetspeed/portal/cms/Sites/destatis/Internet/DE/Navigation/ Publikationen/Querschnittsveroeffentlichungen/StatistikLokal.psml].

42. Kleppin L, Aden C, Schmidt G, Schröder W: Monitoring of genetically modified maize cultivation by means of WebGIS and Google Maps. In Geospatial Crossroads @ Gl_Forum '08: Proceedings of the Geoinformatics Forum Salzburg. Edited by: Car A, Griesebner G, Strobl J. Heidelberg, Wichmann; 2008:170-179.

43. Spatial information of the federal state of Brandenburg. [http://www mugv.brandenburg.de/cms/detail.php/bb2.c.515599.de]

44. Monitoring sites within biosphere reserves in Brandenburg. [http:// lanuweb.fh-eberswalde.de/oeub/dbf.html].

45. Hofmann F, Epp R, Kalchschmid A, Kratz W, Kruse L, Kuhn U, Maisch B, Müller E, Ober S, Radtke J, Schlechtriemen U, Schmidt G, Schröder W, Von der der Ohe W, Vögel R, Wedl N, Wosniok W: Monitoring of Bt-Maize pollen exposure in the vicinity of the nature reserve Ruhlsdorfer Bruch in northeast Germany 2007 to 2008. Umweltwiss Schadst Forsch 2010.

46. Rosi-Marshall EJ, Tank JL, Royer TV, Whiles MR, Evans-White M, Chambers C, Griffith NA, Pokelsek J, Stephen ML: Toxins in transgenic crop byproducts may affect headwater stream. PNAS 2007, 104:16204-16208.

47. Schmidt G, Schröder W: GIS-gestützte Analysen zur möglichen Gefährdung von Naturschutzgebieten durch den Anbau gentechnisch veränderter Kulturpflanzen. Umweltwiss Schadst Forsch 2009, 21(1):76-93.

48. Mattile HR, Sears MK, Duan JJ: Response of Danaus plexippus to pollen of two new Bt-corn events via laboratory bioassay. Entomol Exp Appl 2005, 116:31-41

49. Graef F, Schmidt G, Schröder W, Graef F, Stachow U: Determinig ecoregions for environmental and GMO monitoring networks. Environ Monit Assess 2005, 108:189-203

50. Finck M, Seitz H, Beismann H: Concepts for General Surveillance: VD proposals. Standardisation and harmonisation in the field of GMO monitoring. J Consum Protect Food Safety 2006, 1:11-14.

51. WebGIS application of the Federal Nature Conservation Agency. [http:// www.bfn.de/geoinfo/gvo].

52. Risk Register Genetic Engineering Agriculture. [http://www.risikoregister. de]

53. Klenke $T$, Vögele $F$, Kruse $H$, Lehmann H: PortalU ${ }^{\circledR}$ \& InGrid ${ }^{\circledR}$ - Werkzeuge zur Erstellung, Recherche und Verteilung von Metadaten. In Angewandte Geoinformatik 2007. Edited by: Strobl J, Blaschke Th, Griesebener G. Heidelberg: Wichmann; 2007:338-343.

54. Rissler J, Mellon M: International implications of commercialization (Transgenic Crops) in the ecological risks of engineered crops Cambridge: MIT Press; 1996.

55. OECD (Organisation for Economic Co-operation and Development): Emerging Risks in the 21st Century. An Agenda for Action Paris: OECD; 2003.

56. Wilkinson MJ, Davenport IJ, Charters YM, Jones AE, Allainguillaume J, Butler HT, Mason DC, Raybould AF: A direct regional scale estimate of transgene movement from genetically modified oilseed rape to its wild progenitors. Mol Ecol 2000, 9:983-991.

57. Züghart W, Breckling B: Konzeptionelle Entwicklung eines Monitoring von Umweltwirkungen transgener Kulturpflanzen. UBA-Texte 2003, 50/ 03:1-543. 
58. Janicke $\mathrm{L}$, Janicke $\mathrm{U}$ : Enhancement of a diagnostic wind field model for licensing industrial facilities (TA Luft). Umweltforschungsplan des

Bundesministeriums für Umwelt, Naturschutz und Reaktorsicherheit. Anlagenbezogener Immissionsschutz. Förderkennzeichen (UFOPLAN) 20343 256. Im Auftrag des Umweltbundesamtes Berlin 2004.

doi:10.1186/2190-4715-23-4

Cite this article as: Kleppin et al:: Cultivation of GMO in Germany: support of monitoring and coexistence issues by WebGIS technology. Environmental Sciences Europe 2011 23:4.

\section{Submit your manuscript to a SpringerOpen ${ }^{\mathcal{O}}$ journal and benefit from:}

- Convenient online submission

- Rigorous peer review

- Immediate publication on acceptance

- Open access: articles freely available online

- High visibility within the field

- Retaining the copyright to your article

Submit your next manuscript at $\gg$ springeropen.com 